\title{
Contents of the Following Issue of Opticheskiu Zhurnal (Journal of Optical Technology)
}

DOI: $10.1134 / \mathrm{S} 0030400 \mathrm{X} 10090250$

The following papers will be published in the September issue of Opticheskiu Zhurnal (Journal of Optical Technology), vol. 77, no. 9, 2010.

Physical Optics. Design of Optical V-Antennas (A.I. Denisyuk); Vibrational Spectra of Anharmonic Oscillators of Molecular Crystals (E.K. Galanov).

Computation, Design, and Manufacture of Optical Systems. Specific Design Features of Some Types of Superwide-Angle Lenses (A.Ya. Gebgart); A Diffraction-Refractive Tertiary Spectrum Corrector (G.I. Greisukh, E.G. Ezhov, S.V. Kazin, and S.A. Stepanov).

Optical Instrumentation and Technology. Simulation of Determining Thermodynamic Parameters of High-Temperature Gas Volume by Passive Remote Sensing (A.V. Voitsekhovskiǐ, O.K. Voitsekhovskaya, D.E. Kashirskiı̆, and I.S. Suslova); Astronomical Optical Space Monitoring under Cloudiness Condi- tions (A.B. Bel'skiŭ, S.E. Zdor, V.I. Kolin'ko, and N.G. Yatskevich).

Optical Materials Science and Technology. Techniques of Laser Ceramics Production (S.G. Garanin, A.V. Dmitryuk, A.A. Zhilin, M.D. Mikhailov, and N.N. Rukavishnikov); Dispersion Dependence of Optical Anisotropy and Degree of Depolarization of Fibrous Tissues (D.A. Zimnyakov, G.V. Simonenko, and V.V. Tuchin); Synthesis of Film-Forming Vanadium Oxide Materials and Feasibility Study of the Optical Coating Production on Their Basis (V.V. Kirilenko, B.M. Zhigarnovskiǔ, A.G. Beirakhov, I.P. Malkerova, A.V. Mikhailov, and I.I. Shaganov); NarrowBand Wide-Angle Tunable Steps of an Optical Filter (E.S. Kulagin).

Compiled by L.V. Enushevskaya Translated by S. Belov 